\title{
Ranitidine increases the bioavailability of postprandial ethanol by the reduction of first pass metabolism
}

\author{
A St J M Brown, J R Fiaterone, C P Day, M K Bennett, P J Kelly, O F W James
}

\begin{abstract}
Blood ethanol concentrations after separate oral dosing and intravenous infusion of ethanol $(0 \cdot 15 \mathrm{~g} / \mathrm{kg})$ were measured in 16 control subjects and 13 subjects treated with ranitidine. All subjects underwent routine upper gastrointestinal endoscopy. Peak blood ethanol concentrations, and area under the blood ethanol/time curve, were significantly higher in the ranitidine group after oral, but not intravenous, ethanol administration. The first pass metabolism, as calculated by the difference between the area under the curves, was significantly lower in the ranitidine group. In addition, all subjects withdrawn from ranitidine $(n=6)$ had a significant reduction in peak blood ethanol concentration and area under the curve after repeat dosing with oral ethanol. Both groups were well matched for age, sex, indications for endoscopy, findings at endoscopy, and gastric histology. These findings show that ranitidine increases the bioavailability of low dose ethanol and has possible short term forensic, and longterm physical implications for moderate drinkers who are taking the drug. (Gut 1995; 37: 413-417)
\end{abstract}

Keywords: ethanol metabolism, ranitidine, gastric first pass effect.

Previous studies have shown that ethanol undergoes significant first pass metabolism. ${ }^{1-4}$ At low to moderate doses, blood ethanol concentrations after oral dosing are significantly lower than those seen after intravenous administration. A reduction of this first pass metabolism has been associated with fasting, chronic alcoholism, ${ }^{2}$ female sex, ${ }^{1}$ and with cimetidine, ${ }^{3}$ and aspirin ${ }^{5}$ ingestion. It has been suggested that resultant increase in blood ethanol concentrations could lead to enhanced longterm toxicity, and have important social and forensic implications in relation to the degree of impairment in motor function. It has been suggested that at least part of this first pass metabolism takes place in the stomach mediated by several enzymes of the alcohol dehydrogenase isoenzyme family, ${ }^{2-4}$ known to be present in the gastric mucosa. ${ }^{6}$ The histamine receptor antagonist ranitidine, has been shown to inhibit gastric alcohol dehydrogenase isoenzyme in humans, ${ }^{7}$ but studies in healthy volunteers of the effect of ranitidine ingestion on the bioavailability of ethanol are conflicting. ${ }^{8-28}$ As a high prevalence of problem drinking is encountered in patients with gastrointestinal disease, in particular peptic disorders, ${ }^{29}$ increased bioavailability of ethanol during ranitidine treatment is of potential clinical importance. We sought to determine the effect of ranitidine on the bioavailability of ethanol in a population referred for assessment of gastrointestinal symptoms who were therefore potential recipients of ranitidine as treatment. This also enabled an investigation of the potential effects of differences in gastric histology on ethanol bioavailability.

\section{Methods}

\section{Subjects}

Consecutive adult subjects due to undergo routine, outpatient, upper gastrointestinal endoscopy were recruited to the study. Subjects with an alcohol intake of greater than $40 \mathrm{~g} /$ day, previous gastric surgery, those receiving $\mathrm{H}_{2}$ receptor antagonists other than ranitidine, and those with major concomitant medical problems were excluded. No patient was receiving concomitant treatment at the time of the studies. Table I shows subject characteristics, indications for endoscopy, and endoscopic and histological findings.

Twenty nine subjects ( 15 male, 14 female) gave informed consent for the study, which was approved by the joint ethics committee of the University of Newcastle upon Tyne and Newcastle Health Authority. All patients were white. Thirteen subjects (six males, seven females) had been prescribed ranitidine $150 \mathrm{mg}$ twice daily for at least three weeks (median six weeks, range 3-48) before

TABLE I Subject analysis

\begin{tabular}{lll}
\hline & $\begin{array}{l}\text { Ranitidine group } \\
(n=13)\end{array}$ & $\begin{array}{l}\text { Control group } \\
(n=16)\end{array}$ \\
\hline $\begin{array}{l}\text { Median age (range) } \\
\text { Sex (male:female) }\end{array}$ & $54(43-72)$ & $52(29-86)$ \\
Indication for endoscopy & $6: 7$ & $9: 7$ \\
Abdominal pain & 5 & 8 \\
Anaemia & 3 & 4 \\
Peptic ulcer review & 2 & 0 \\
Other & 3 & 4 \\
Endoscopic findings & & 11 \\
$\quad$ Normal & 7 & 3 \\
Gastric erythema & 3 & 1 \\
Peptic ulcer & 3 & 1 \\
Other & 0 & 6 \\
Gastric histology & & 4 \\
$\quad$ Chronic gastritis & 5 & 4 \\
Atrophic gastritis & 3 & 2 \\
$\quad$ Normal & 3 & \\
Other/not available & 2 & \\
\hline
\end{tabular}

Departments of
Medicine
A St J M Brown
J R Fiaterone
C P Day
O F W James
Histopathology
M K Bennett
and Statistics
P J Kelly
University of
Newcastle upon Tyne
Correspondence to:
Professor O F W James,
Department of Medicine,
William Leech Building,
Medical School, University
of Newcastle upon Tyne,
Framlington Place,
Newcastle upon Tyne
NE2 4HH.
Accepted for publication
18 January 1995


TABLE II Oral studies

\begin{tabular}{lllll}
\hline & $\begin{array}{l}\text { Ranitidine group } \\
(n=13)(95 \% \mathrm{CI})\end{array}$ & $\begin{array}{l}\text { Control group } \\
(n=16)(95 \% \mathrm{CI})\end{array}$ & $\begin{array}{l}\text { Estimated mean } \\
\text { difference }(95 \% \mathrm{CI})\end{array}$ & $\begin{array}{l}p \\
\text { Value }\end{array}$ \\
\hline $\begin{array}{l}\text { Median peak ethanol } \\
(\mathrm{mg} / 100 \mathrm{ml})\end{array}$ & $21.0(15 \cdot 2,24 \cdot 0)$ & $10 \cdot 0(6.9,14 \cdot 9)$ & $9 \cdot 7(3 \cdot 8,15 \cdot 0)$ & 0.003 \\
$\begin{array}{c}\text { Area under curve } \\
(\mathrm{mg} / 100 \mathrm{ml} / \mathrm{h})\end{array}$ & $16.5(11 \cdot 9,20 \cdot 8)$ & $7.5(4 \cdot 8,9 \cdot 5)$ & $8 \cdot 8(4 \cdot 3,13 \cdot 8)$ & 0.002 \\
\hline
\end{tabular}

endoscopy by their referring medical practitioner. Sixteen subjects (the 'control' group), were not receiving ranitidine. Those taking ranitidine continued to take the treatment during the study period, including a supervised dose of $150 \mathrm{mg}$ at 0800 on the morning of the study. Patient compliance was ascertained by direct questioning.

\section{Ethanol pharmacokinetic studies}

Each subject had separate oral and intravenous ethanol administration $(0.15 \mathrm{~g} / \mathrm{kg}$ body weight, median dose $10.8 \mathrm{~g}$, range $7 \cdot 5-14 \cdot 7$ ) performed one week apart. Each study was performed one hour after a standard three course hospital lunch, eaten in the presence of the investigator. Subjects were free to choose from the patient menu, and all meals, while not identical, had a similar energy value and
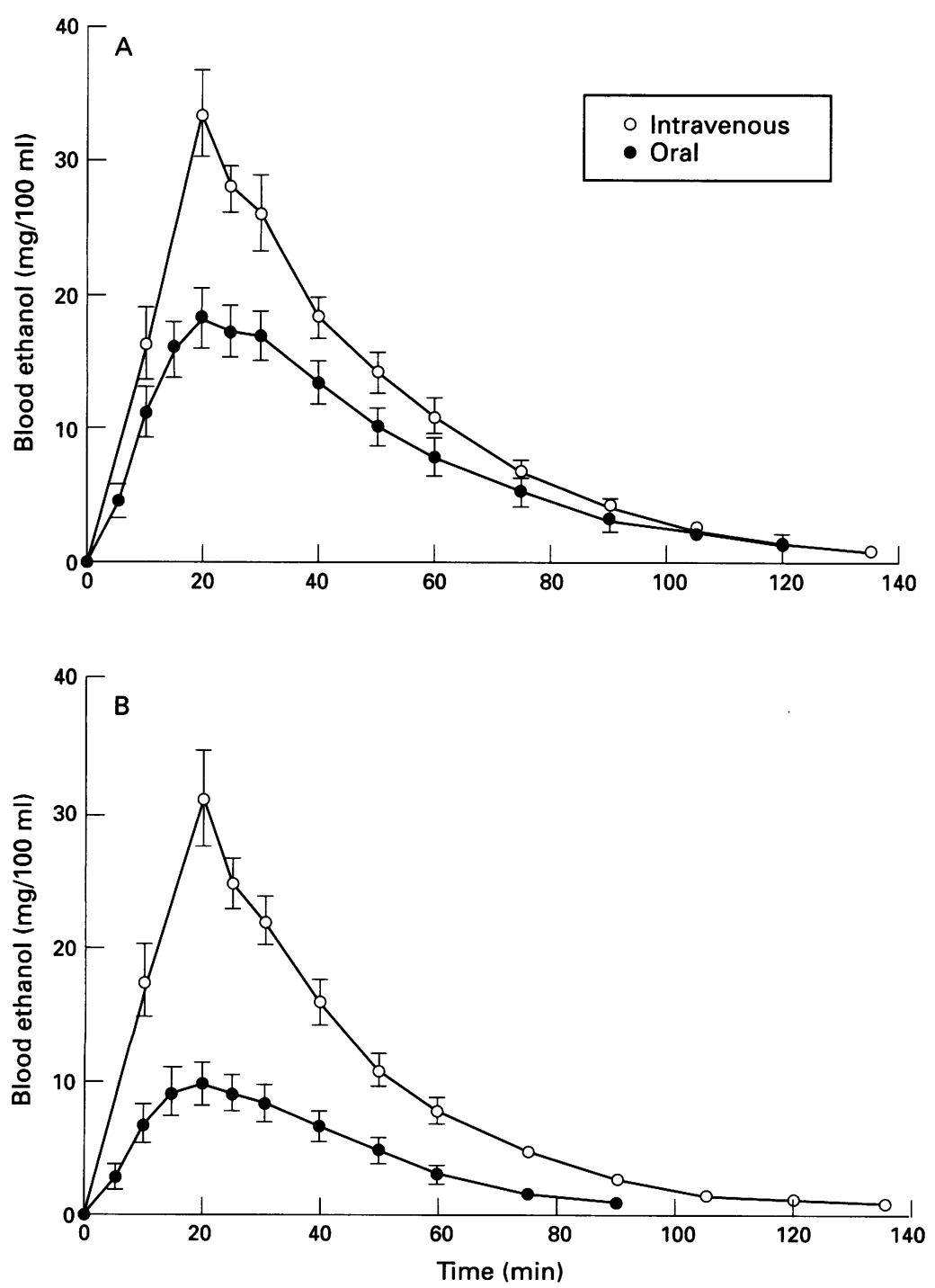

Figure 1: Mean blood ethanol concentrations after oral and intravenous ethanol (bars indicate SEM). (A) Subjects taking ranitidine; (B) control subjects. balance of carbohydrate, fat, and protein (average $677 \mathrm{kcal}, 33 \mathrm{~g}$ protein, $31 \mathrm{~g}$ fat, $61 \mathrm{~g}$ carbohydrate). Oral ethanol ( $90 \%$ ethanol BP, James Burrough, Witham, UK) was given in $200 \mathrm{ml}$ of orange juice and was drunk within two minutes. Intravenous ethanol (dehydrated absolute alcohol, Martindale Pharmaceuticals, Romford, UK) was given in $200 \mathrm{ml}$ of $5 \%$ dextrose and infused using a volumetric infusion pump (IMED, model 960, Abingdon, UK). Blood was collected by an indwelling intravenous cannula at times $0,5,10,15,20$, $25,30,40,50,60,75,90,105,120$, and 135 minutes and placed in fluoride oxalate tubes. The specimens were stored at $-20^{\circ} \mathrm{C}$ and analysed within 72 hours. Blood ethanol concentrations were determined by a liquid gas chromatography assay. ${ }^{30}$ The oral study was performed first and the infusion time for the intravenous study was set such that the peak blood ethanol concentration would occur at the same time in both studies (median time 20 minutes, range 10-40). Six subjects in the ranitidine group had a further oral ethanol pharmacokinetic study performed two weeks after ranitidine had been withdrawn.

\section{First pass metabolism}

The first pass metabolism of ethanol was determined in each patient by measuring the difference in area under the curve (AUC) of the blood ethanol/time curves. The AUCs were calculated using the trapezoidal method of integration. First pass metabolism was calculated and expressed as the difference between the AUC(intravenous) and AUC(oral).

\section{Gastric pathology}

Upper gastrointestinal endoscopy was performed with an Olympus GIF IT20 gastroscope, and two to four biopsy specimens were taken by pinch biopsy forceps from separate sites in the gastric antrum not affected by macroscopically focal abnormality. The biopsy specimens were assessed 'blind' by one experienced gastrointestinal histopathologist. Specimens from three of the subjects were considered inadequate for histological assessment.

\section{Statistics}

Data were analysed with the Wilcoxon signed rank test and Mann-Whitney $U$ test where appropriate. Estimated differences in medians and associated confidence intervals were obtained using the methods described by Gardner and Altman. ${ }^{31} \mathrm{p}$ Values $<0.05$ were taken as significant.

\section{Results}

There were no significant differences in age, sex, indication for endoscopy, endoscopic findings or gastric histology between the ranitidine and control groups (Table I).

In the ranitidine group the median peak blood ethanol concentration and AUC after oral ethanol were significantly greater $(21 \cdot 0 \mathrm{v}$ 
TABLE III Intravenous studies

\begin{tabular}{lllll}
\hline & $\begin{array}{l}\text { Ranitidine group } \\
(n=13)(95 \% \mathrm{CI})\end{array}$ & $\begin{array}{l}\text { Control group } \\
(n=16)(95 \% \mathrm{CI})\end{array}$ & $\begin{array}{l}\text { Estimated mean } \\
\text { difference }(95 \% \mathrm{CI})\end{array}$ & $\begin{array}{l}p \\
\text { Value }\end{array}$ \\
\hline $\begin{array}{c}\text { Median peak ethanol } \\
(\mathrm{mg} / 100 \mathrm{ml})\end{array}$ & $38.0(29 \cdot 6,44.7)$ & $34.0(27 \cdot 0,38.3)$ & $4.0(-5.0,13.0)$ & 0.3 \\
$\begin{array}{c}\text { Area under curve } \\
(\mathrm{mg} / 100 \mathrm{ml} / \mathrm{h})\end{array}$ & $24.0(19.9,29 \cdot 2)$ & $18.5(16.8,22.8)$ & $5.0(-0.25,10.0)$ & 0.06 \\
\hline
\end{tabular}

$10.0 \mathrm{mg} / 100 \mathrm{ml}$ and $16.5 v 7.5 \mathrm{mg} / 100 \mathrm{ml} / \mathrm{h}$ respectively) than in the control group (Fig 1, Table II). In contrast there were no significant differences between the groups in the median peak blood ethanol concentration and AUC after intravenous ethanol (Table III).

The first pass metabolism of this dose of ethanol (as calculated by the difference between AUC(intravenous) and AUC(oral)) was therefore significantly lower in the ranitidine treated group (estimated median difference between groups $5.0 \mathrm{mg} / 100 \mathrm{ml} / \mathrm{h}$ (Fig 2, Table IV).

In addition, peak blood ethanol concentrations and AUC(oral) were significantly reduced in all subjects $(n=6)$ when restudied after the withdrawal of ranitidine (Fig 3, Table V).

No relation was determined between the variables of age, sex, indication for endoscopy, endoscopic findings or gastric histology and ethanol pharmacokinetics in the group as a whole.

\section{Discussion}

The debate over the contribution of the gastric mucosa to first pass metabolism of ethanol, and the effect of various $\mathrm{H}_{2}$ receptor antagonists on that role, continues. The results of this study show that the bioavailability of low dose ethanol was increased by concurrent ingestion of ranitidine in therapeutic doses and that the most probable explanation is a reduction in the first pass metabolism. Gastric mucosa contains a number of different alcohol dehydrogenase isoenzymes including one with a high $\mathrm{K}_{\mathrm{m}}$ for ethanol, which is not found in the liver, ${ }^{32}$ and, as ranitidine is a potent inhibitor of gastric alcohol dehydrogenase isoenzyme in vitro, we believe that such inhibition could contribute to the observed reduction in first pass metabolism. ${ }^{7}$

In a review article Levitt puts forward a convincing, though theoretical, argument that previous estimations of the percentage of ethanol metabolised by the gastric mucosa have been greatly exaggerated. ${ }^{33}$ Nevertheless, of the 21 studies reviewed in that article, ${ }^{2} 810-28$ no fewer than 14 showed peak blood ethanol concentrations after oral intake that were higher after treatment with either cimetidine or ranitidine, although in only seven were the differences statistically significant. ${ }^{11-13192022} 23$ Levitt suggests that, rather than an effect on gastric alcohol dehydrogenase isoenzyme activity, the results are caused by the effect of the $\mathrm{H}_{2}$ receptor antagonists on either ethanol absorption or hepatic ethanol metabolism. The lack of significant effect of ranitidine on the pharmacokinetics of intravenous ethanol seen in this study, however, shows that hepatic metabolism is unlikely to be affected by the drug, and cannot therefore satisfactorily explain the observed difference in the oral studies. It has also been shown previously that ranitidine has no affect on hepatic blood flow. ${ }^{34}$ Similarly, it is unlikely that ranitidine enhances the absorption of ethanol by increasing the rate of gastric emptying as ranitidine has been shown in at least one study to delay gastric emptying in both healthy volunteers and subjects with duodenal ulceration. ${ }^{35}$ Likewise, it is doubtful that the increase in gastric $\mathrm{pH}$ resulting from ranitidine has any effect on the absorption of ethanol as the $\mathrm{H}_{2}$ receptor antagonist famotidine and the proton pump inhibitor omeprazole have not been

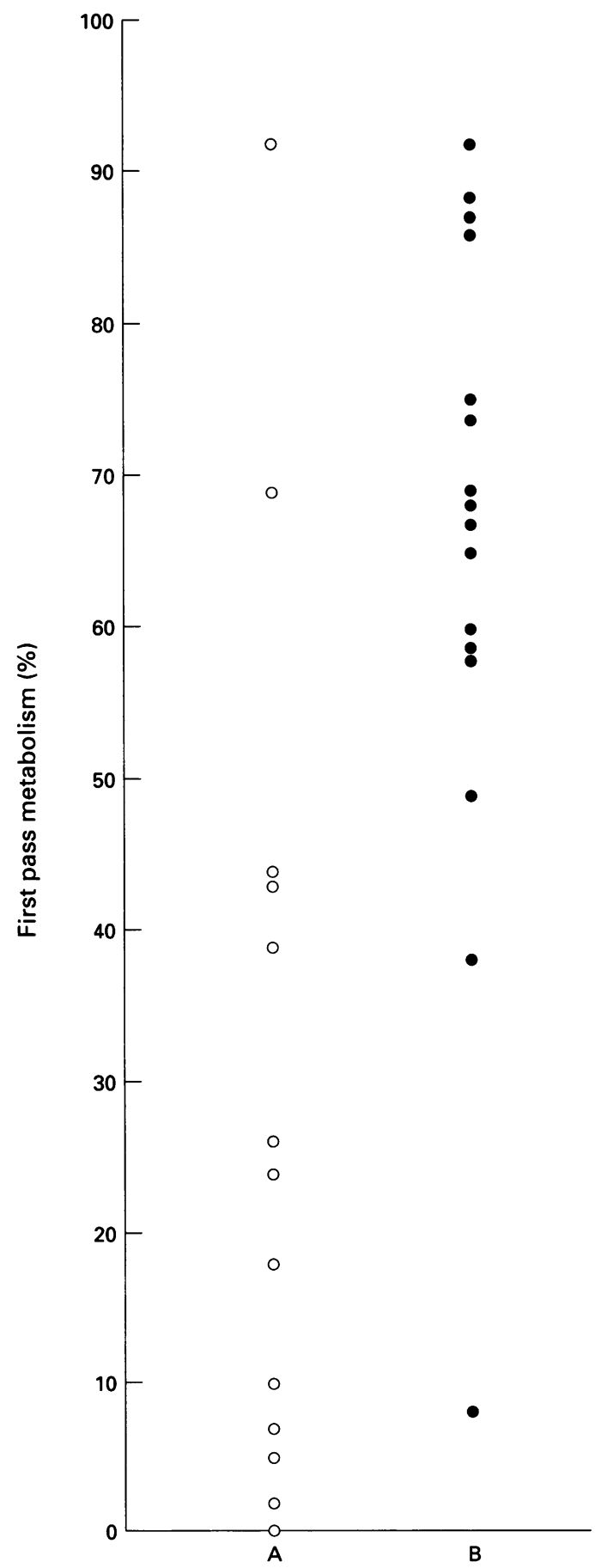

Figure 2: Individual first pass metabolism expressed as a percentage of total metabolism. (A) Subjects taking ranitidine; (B) control subjects. 
TABLE IV Calculated first pass metabolism of ethanol

\begin{tabular}{lllll}
\hline & $\begin{array}{l}\text { Ranitidine group } \\
(n=13)(95 \% \mathrm{CI})\end{array}$ & $\begin{array}{l}\text { Control group } \\
(n=16)(95 \% \mathrm{CI})\end{array}$ & $\begin{array}{l}\text { Estimated median } \\
\text { difference }(95 \% \mathrm{CI})\end{array}$ & $\begin{array}{l}p \\
\text { Value }\end{array}$ \\
\hline $\begin{array}{l}\text { Median difference of } \\
\text { AUC(IV) minus }\end{array}$ & $\begin{array}{l}8 \cdot 2(4 \cdot 2,12 \cdot 4) \\
\mathrm{p}=0.003\end{array}$ & $\begin{array}{l}13 \cdot 2(10 \cdot 4,15 \cdot 9) \\
\mathrm{p}<0.0001\end{array}$ & $5 \cdot 0(0 \cdot 6,10 \cdot 0)$ & 0.03 \\
$\begin{array}{l}\text { AUC(oral) }(\mathrm{mg} / \\
100 \mathrm{ml} / \mathrm{h})\end{array}$ & & & & \\
\hline
\end{tabular}

IV=intravenous.

shown to have any effect on the bioavailability of ethanol ${ }^{9}$ (although studies strictly comparable to our own have not been carried out). The second finding also argues against the effect of ranitidine on gastric alcohol dehydrogenase isoenzyme activity caused by a nonspecific $\mathrm{pH}$ effect. Further confirmation of the effect of ranitidine on the bioavailability of ethanol is provided by the reduction in peak blood ethanol concentration and AUC(oral) in all subjects withdrawn from treatment. These subjects did not have acid related lesions on endoscopy and therefore the observed decrease in bioavailability could not result from resolution of gastric mucosal abnormality. Furthermore, there was no consistent relation between gastric histology and bioavailability of ethanol in this study irrespective of ranitidine ingestion.

Previous studies examining the bioavailability of ethanol and ranitidine have used young healthy male volunteers and experimental conditions such as large doses of ethanol in the fasting state, in which the first pass metabolism of alcohol would be reduced. Our study population, however, with gastrointestinal symptoms or disorders are the very subjects likely to be prescribed $\mathrm{H}_{2}$ receptor antagonists and constitute, we therefore believe, a

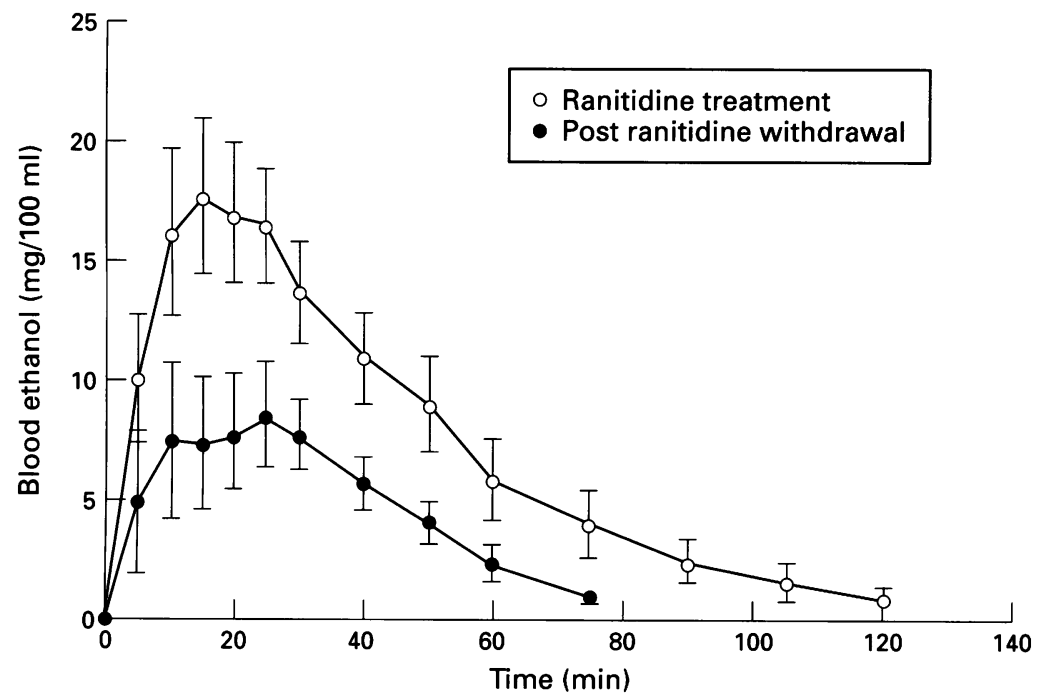

Figure 3: Mean blood ethanol concentrations after oral ethanol in six subjects while taking ranitidine and two weeks after ranitidine withdrawal (bars indicate SEM).

TABLE V Repeat studies after ranitidine withdrawal

\begin{tabular}{|c|c|c|c|c|}
\hline & $\begin{array}{l}\text { During ranitidine } \\
\text { treatment } \\
(n=6)(95 \% C I)\end{array}$ & $\begin{array}{l}\text { After ranitidine } \\
\text { withdrawal } \\
(n=6)(95 \% C I)\end{array}$ & $\begin{array}{l}\text { Estimated median } \\
\text { difference }(95 \% \text { CI) }\end{array}$ & $\stackrel{p}{\text { Value }}$ \\
\hline \multirow{2}{*}{$\begin{array}{l}\text { Peak blood ethanol } \\
(\mathrm{mg} / 100 \mathrm{ml}) \\
\text { Area under curve } \\
(\mathrm{mg} / 100 \mathrm{ml} / \mathrm{h})\end{array}$} & $16 \cdot 9(13 \cdot 6,26 \cdot 8)$ & $7 \cdot 0(4 \cdot 9,19 \cdot 7)$ & $9 \cdot 0(-0.25,19 \cdot 0)$ & 0.06 \\
\hline & $15 \cdot 1(8 \cdot 9,27 \cdot 0)$ & 5.9 & $9 \cdot 3(5 \cdot 5,13 \cdot 5)$ & $<0.05$ \\
\hline
\end{tabular}

clinically more relevant group. Similarly, we feel that the use of postprandial consumption of alcohol in this study is more relevant to 'real life' than others whose findings were made in the fasting state. None the less we cannot fully explain the difference between the findings of this study and that of Fraser et $a^{26}$ who found no effect of one week pretreatment with ranitidine on oral ethanol kinetics in young men in the fed state using $0.3 \mathrm{~g} / \mathrm{kg}$ ethanol. Possibly the fairly short period of pretreatment used in that study may have been insufficient to produce the change in ethanol pharmacokinetics.

Ethanol complies with zero order (concentration independent) kinetics when blood concentrations are greater than the Michaelis constant $\left(\mathrm{K}_{\mathrm{m}}\right)$, which is approximately $4 \mathrm{mg} / \mathrm{dl}^{36}$ Therefore, the area under the blood ethanol/time curve is determined by the rate of absorption or infusion of oral and intravenous ethanol respectively. Previous studies have been criticised for their use of AUC to calculate first pass metabolism. ${ }^{33}$ This has been overcome in this study, by obtaining simultaneous peak blood ethanol concentrations in both oral and intravenous studies, thus ensuring that the pharmacokinetic model used to determine first pass metabolism is appropriate.

In this study the dose of ethanol was chosen to maximise the first pass metabolism, which may account for as much as $80-90 \%$ of the total metabolism seen (Fig 2). First pass metabolism is of importance at twice the dose used in this study ${ }^{1}$ and is probably so at larger doses consumed more slowly in the usual social setting compared with rapid consumption hitherto used experimentally, particularly in the fasting state. As risk levels for the development of alcoholic liver disease in susceptible subjects have been claimed to be as low as $40 \mathrm{~g}$ of ethanol per day in men and less in women, ${ }^{37}$ longterm reduction of first pass metabolism of low to moderate doses of ethanol associated with prolonged maintenance treatment with ranitidine, one of the most widely prescribed of all drugs, may be clinically significant. Similarly, while the concentrations of blood alcohol attained by patients in this study did not exceed the limits of legal significance, they did in some cases none the less approach them, even in the low doses used, contradicting previous claims that any reduction in first pass metabolism of ethanol brought about by $\mathrm{H}_{2}$ receptor antagonists is of no significance in patients who drive.

$\mathrm{AB}$ and $\mathrm{JF}$ were supported by the BDF and Research into Ageing. CPD was supported by a MRC Clinician Scientist Fellowship.

1 Frezza M, Di Padova C, Pozzato G, Terpin M, Baraona E, Lieber CS. High blood alcohol levels in women. The role of decreased gastric alcohol dehydrogenase activity and first pass metabolism. N Engl f Med 1990; 322: 95-9.

2 Caballeria J, Baraona E, Rodamilans M, Lieber CS. Effects of cimetidine on gastric alcohol dehydrogenase activity and blood ethanol levels. Gastroenterology 1989; 96: 388-92.

3 DiPadova C, Worner TM, Julkunen RJK, Lieber CS. Effects of fasting and chronic alcohol consumption on the first pass metabolism of ethanol. Gastroenterology 1987; 92: 1169-73.

4 Ueno Y, Fukunaga T, Mizoi Y, Adachi J, Fujiwara S. A pharmacokinetic study of ethanol elimination. Fast pass metabolism and elimination rate. $尹$ pn $\mathcal{f}$ Alcohol Drug Dependence 1990; 25: 103-15. 
5 Roine R, Gentry RT, Hernandez-Munoz R, Baraona E, Lieber CS. Aspirin increases blood alcohol concentrations
in humans after ingestion of ethanol. $¥ A M A 1990 ; 264:$ in humans

6 Peastalozzi DM, Buhler R, von Wartburg JP, Hess $M$. Immunohistochemical localisation of alcohol dehydrogenase in the human gastrointestinal tract. Gastroenterology 1983; 85: 1011-6.

7 Hernandez-Munoz R, Caballiera J, Baraona E, Uppal R, Greenstein R, Lieber CS. Human gastric alcohol dehydrogenase: its inhibition by $\mathrm{H} 2$ receptor antagonists and its effect on the bioavailability of ethanol. Alcohol Clin Exp Res 1990; 14: 946-50.

8 Dobrilla G, de Pretis G, Piazza L, Chilovi F, Comberlato $\mathbf{M}$, Valentini $\mathbf{M}$, et al. Is ethanol affected by oral administration of cimetidine and ranitidine at therapeutic doses? tration of cimetidine and ranitidine at

9 Roine R, Di Padova C, Frezza M, Hernandez-Munoz R, Baraona E, Lieber CS. Effects of omeprazole, cimetidine and ranitidine on blood ethanol concentrations. Gastroenterology 1990; 98: A114.

10 Tanaka E, Nakamura K. Effects of $\mathrm{H} 2$ receptor antagonists on ethanol metabolism in Japanese volunteers. Br 7 Clin Pharmacol 1988; 26: 96-9.

11 DiPadova C, Roine R, Frezza M, Gentry T, Baraona E, Lieber CS. Effects of ranitidine on blood alcohol levels after ethanol ingestion. $\mathcal{F A M A} 1992 ; 267: 83-6$.

12 Fraser AG, Hudson M, Sawyerr AM, Rosalki SB, Pounder RE. The effect of ranitidine on the post-prandial absorp-
tion of a low dose of alcohol. Aliment Pharmacol Ther 1992; 6: 267-71.

13 Palmer RH, Frank WO, Nambi P, Wetherington JD, Fox MJ. Effects of various concommitant medications on gastric alcohol dehydrogenase and the first pass metabolism of ethanol. Am $\mathcal{f}$ Gastroenterol 1991; 86: 1749-53.

14 Ettienne $M$, Kremmers P, Belaiche J. Influence of antisecretory drugs on gastric alcohol dehydrogenase activity in man. Gastroenterology 1991; 100: A521.

15 Fraser AG, Hudson M, Sawyerr AM, Smith MS, Sercombe J, Rosalki SB, et al. Ranitidine has no effect on post-breakfast ethanol absorption. Am $\mathcal{F}$ Gastroenterol 1993; 88: 217-21.

16 Holtzman G, Singer MV. Histamine receptor antagonists and blood alcohol levels. Dig Dis Sci 1988; 33: 767-8.

17 Fraser AS, Sawyerr AM, Hudson M, Smith M, Rosalki S, Pounder RE. Ranitidine, cimetidine and famotidine have no effect on post-prandial high dose $(0.8 \mathrm{~g} / \mathrm{kg})$ alcohol absorption in healthy male volunteers. Gastroenterology 1992; 102: A70.

18 Fraser AG, Prewett EJ, Hudson M, Sawyerr AM, Rosalki SB, Pounder RE. Ranitidine has no effect on post-prandial absorption of alcohol $(0.6 \mathrm{~g} / \mathrm{kg})$ after an evening meal. European fournal of Gastroenterology and Hepatology 1992; 4: 43-7.

19 Webster LK, Jones DB, Smallwood RA. Influence of cimetidine and ranitidine on ethanol pharmacodynamics. Aust NZ F Med 1985; 15: 359-60.
20 Guram M, Howden CW, Holt S. Further evidence for an interaction between alcohol and certain H2-receptor interaction between alcohol and certain H2-recep

21 Seitz HK, Bosche J, Czygan P, Veith S, Simon B, Kommerrel B. Increased blood ethanol levels following cimetidine but not ranitidine. Lancet 1983; i: 760.

22 Feely J, Wood AJJ. Effects of cimetidine on the elimination and actions of ethanol. $\mathscr{f} A M A 1982 ; 274: 2819-21$.

23 Norpoth VT, Kneip M, Oehmichen M, Staak M, Iffland R, Kaferstein $\mathrm{H}$. The kinetics of alcohol and psychophysical performance after taking $\mathrm{H} 2$ receptor blockers. Beitr Gerichtl Med 1986; 44: 1-44.

24 Johnson KI, Fenzl E, Hein B. Einfluss von Cimetidine auf den Abbau und die Wirkung des Alkohols. Arznei Mittelforschung 1984; 34: 734-6.

25 Raufman J-P, Notar-Francesco V, Raffaniello RD, Strauss EE. Histamine-2 receptor antagonists do not alter serum ethanol levels in fed, non-alcoholic men. Ann Intern Med ethanol levels in fed

26 Fraser AG, Prewett EJ, Hudson M, Sawyer AM, Rosalki SB, Pounder RE. The effect of ranitidine, cimetidine or famotidine on low-dose post-prandial alcohol absorption. Aliment Pharmacol Therap 1991; 5: 263-72.

27 Kleine M, Eith D. Comparative trial in volunteers to investigate ethanol (ETOH), ranitidine (R) interactions. Gastroenterology 1992; 102: A98.

28 Toon S, Khan A, Langley S, Mullins F, Rowland M. Lack of effect of high dose ranitidine on the post-prandial pharmacokinetics of alcohol. Gut 1992; 33 (suppl 1): S10.

29 Holt S. Alcohol and $\mathrm{H} 2$ receptor antagonists: over the counter, under the table? Am F Gastroenterol 1990; 85: counter,

30 Cooper JDH. Determination of blood alcohol by gas chromatography. Clin Chim Acta 1971; 33: 483-5.

31 Campbell MJ, Gardner MJ. Calculating confidence intervals for some non-parametric analyses. In: Gardner MJ, Altman DG. Statistics with confidence. London: BMJ Publishing Group, 1989: 71-8.

32 Moreno A, Pares X. Purification and characterisation of a new alcohol dehydrogenase from human stomach. $\mathrm{f}$ Biol Chem 1991; 226: 1128-33.

33 Levitt MD. Lack of clinical significance of the interaction between H2-receptor antagonists and ethanol. Aliment Pharmacol Ther 1993; 7: 131-8.

34 Dunk AA, Jenkins WJ, Burroughs AK, Walt RP, Osuafor TO, Sherlock S, et al. The effect of ranitidine on the plasma clearance and hepatic extraction of indocyanine green in patients with chronic liver disease. $\mathrm{Br} \mathcal{F}$ Clin Pharmacol 1983; 16: 117-20.

35 Jonderko $\mathrm{K}$. Influence of oral cimetidine and ranitidine on gastric emptying in active duodenal ulcer. $f$ Clin Gastroenterol 1988; 10: 143-9.

36 Holford NHG. Clinical pharmacokinetics of ethanol. Clin Pharmacokinet 1987; 13: 273-92.

37 Lieber CS, DeCarli LM. Hepatotoxicity of ethanol. $f$ Hepatol 1991; 12: 394-401. 